\title{
TCOM \\ RRI \& science museums; prototyping an exhibit for reflection on emerging and potentially controversial research and innovation
}

\section{Marjoleine G. van der Meij, Jacqueline E. W. Broerse and Frank Kupper}

\begin{abstract}
To unravel how science museums can prepare citizens for reflection on research and innovation, this study evaluates a playful exhibit prototype, Opinion Lab (OL). The OL made children and parents reflect on synthetic biology (SB), supported by conversation exercises, citizen-narratives, and futuristic scenarios. We analysed $26 \mathrm{OL}$ test sessions performed in NEMO science museum Amsterdam. The prototype appeared to support participants in opinion forming, counter-argument incorporation and extrapolation. Also, reflection on deeper questions such as 'what is nature?' evoked understanding for alternative viewpoints. These findings show that playful exhibits, like the OL, potentially facilitate dialogue in science museums very well.
\end{abstract}

Keywords

Public engagement with science and technology, Public perception of science and technology, Science centres and museums

Responsible research and innovation (hereafter RRI) promotes the inclusion of societal actors in research and innovation (R\&I), especially when R\&I are potentially controversial [Owen, Macnaghten and Stilgoe, 2012; Stilgoe, Lock and Wilsdon, 2014]. Such inclusion requires organization of processes and events at which societal actors meet to reflect on, and exchange, interests, concerns, values and ideas about motives and purposes of R\&I [Stilgoe, Owen and Macnaghten, 2013]. Such inclusive reflection can be fruitful for both R\&I and non-R\&I participants. Namely, it gives citizens and stakeholders the opportunity to have a say in R\&I, while it helps R\&I practitioners and institutes to find directions for societally responsive R\&I development [Gibbons, 1999; Korthals, 2011; Owen, Macnaghten and Stilgoe, 2012; Stilgoe, Owen and Macnaghten, 2013].

As emerging R\&I fields are often shrouded in uncertainties, inclusive reflection involves processes of sensing making, or 'framing' [McKee, 2003; van Hulst and Yanow, 2014]. This sense making can be challenging for participants [Macnaghten and Chilvers, 2014; Sykes and Macnaghten, 2013]. Therefore, it is good to develop safe settings in which people can practice their skills of sense making on controversial R\&I [see e.g. Boerwinkel, Swierstra and Waarlo, 2014]. In other words, environments are needed in which people can practice reflection on R\&I framing so that they are prepared for reflection in RRI contexts. 
Although scholars consider that science museums have a potential role in supporting reflection on R\&I [e.g. Bandelli and Konijn, 2015; Bandelli, Konijn and Willems, 2009; Delicado, 2009; Skydsgaard, Møller Andersen and King, 2016; Stocklmayer, 2005; Yaneva, Rabesandratana and Greiner, 2009], only a few have investigated exhibition designs that aim to train visitors in R\&I frame reflection. In 1992, Macdonald and Silverstone analysed an exhibit displaying scientific controversy related to food R\&I. They concluded that the museum seemed conservative in triggering reflection on various ways of framing R\&I on food, because it displayed only one sentence about disagreement among scientists in the exhibit texts [Macdonald and Silverstone, 1992]. In 2009, Delicado came to a comparable conclusion in her analysis of a Portuguese exhibition about Genetic Modified Organisms (GMOs) in food. This exhibition, despite its aim to stimulate reflection on controversy, also appeared to present a rather one-sided framing of GMOs, namely that humans have always selected the best foods for cultivation and that the dangers of GMOs are controllable [Delicado, 2009].

More recently, Skydsgaard, Møller Andersen and King [2016] analysed a Danish exhibition about the human body in which frame-diversity was explicitly built-in, namely by means of so-called personal narratives in addition to expert narratives. They established that the use of narratives in the exhibit design triggered reflection among the exhibition's (early high school aged) visitors [Skydsgaard, Møller Andersen and King, 2016]. Nevertheless, they did not explicitly analyse how the composition of the narratives or other tools triggered reflection on framing. Such research could help to further ideas on the use of narratives and other tools so that science museums can design exhibitions that facilitate frame-diverse R\&I reflection, and thereby play a role in training visitors' development of scientific citizenship skills [cf. Bandelli and Konijn, 2015] for RRI contexts.

This study examines the potential role of science museums in facilitating reflection on R\&I framing to prepare visitors for reflection in RRI contexts. We designed an exhibit prototype, named 'Opinion Lab' (hereafter OL), to support frame reflective conversations between children aged eight to twelve and their parents on an emerging R\&I field. As exhibit topic, we chose synthetic biology (hereafter SB). SB takes an engineering approach to biology, creating organisms or organism-like systems from scratch, making it a more drastic intervention to cells and organisms than in conventional biotechnology [Boldt, 2016]. In the autumn of 2016, a Dutch policy advisory institute addressed the potential of SB in terms of disease diagnosis and treatment, biofuels, decomposable plastics, food production and fibres for clothing [Rerimassie et al., 2016]. This advisory report concluded that Dutch legislation for bio-technology applications is out-dated and recommended that citizens should be consulted before SB innovations are available, in order to create a societally responsible agenda for its further development [Rerimassie et al., 2016]. This is consistent with scholars who have argued that SB needs deliberation in the societal arena to ensure RRI [e.g. Blümel, 2016; Boldt, 2016; Piaggio et al., 2017]. Given that consultations with citizens will probably take place in the future, we have designed the OL to support frame reflection on SB applications in healthcare, sustainable development and food.

The OL embedded several hands-on and conversational activities, images of potential SB applications and audio-narratives, inspired by research into framing and science exhibit design. We investigated how the OL contributed to reflection 
on SB framing between the children and their parents. To gather data, we asked visitors to NEMO science museum, Amsterdam, to take part in OL test sessions of 20 minutes, facilitated by a researcher. Transcripts of the 26 child-parent-facilitator conversations that took place during the OL testing gave insights into (1) how the SB framing processes of the child-parent duos during conversations, and (2) the contribution of the OL design on these processes. Before we describe the OL design and our study findings, we first elaborate on the framing theory, on which this study is based.

Many new situations that we encounter as humans may, at first, seem complex and difficult to understand. This might particularly be the case for new and emerging R\&I fields, such as SB. The perspectives that we create when we make sense of these complex realities are called 'frames': underlying structures of belief, perception and appreciation [Schön and Rein, 1994]. The pragmatist philosopher John Dewey argued that an indeterminate situation is only transformed into a problematic situation when we start to inquire and reflect on it from our personal, subjective experience [Dewey, 1910]. Schön and Rein adopted Dewey's theory of inquiry and focused on the role of 'framing'. In an effort to understand new, complex situations, individuals select different features and relations within a story. Each story places the selected set of features and relations within a particular frame.

Following Schön and Rein [1994], van Hulst and Yanow [2014] differentiate between different elements of this process: selection is concerned with the process of highlighting particular aspects amongst a range of possible features; naming is the process of assigning meaning to a situation based on what we know; and categorizing represents the process of drawing disparate elements into a pattern. All three elements play a role in the process of unconscious selecting ways of seeing.

Storytelling is a subsequent element of framing, according to van Hulst and Yanow [2014], which binds selected elements and relations into a coherent pattern. Frames are narrative devices in that they attribute sense to a situation. Moreover, the role of storytelling signifies that framing is an inter-subjective process. In this way, individuals make sense of a phenomenon by building upon their interactions with other people.

As a result of the selection, naming and categorizing processes, every person develops a different story with a perspective on the situation at stake. Schön studied, amongst other things, how these views influenced the actions of professionals in practice [1983]. Building on that line of thought, Grin and Graaf [1996] developed an analytical framework to understand actor perspectives. They distinguished between first-order notions that relate to concrete and specific situations and second-order notions that involve more generic conceptions that frame how an actor approaches the specific situation. In Grin and van der Graaf's framework [1996], first-order notions concern problem definitions or views of preferred solutions, whereas second-order notions comprise underlying values, assumptions, preferences and interests. These second-order notions are often less obviously expressed in conversations and may remain unnoticed. At the same time, they also influence the position of an actor in relation to a specific situation. To achieve mutual understanding between people, the elicitation of first- and second-order notions is hence beneficial. 
Given this theoretical background, it is likely that individuals have numerous ways of framing SB, its problematic issues and potential contribution to health, energy provision and food production [see e.g. Ancillotti et al., 2016]. Therefore, learning formats, such as exhibits in science museums that prepare people for RRI-related reflection, should ideally support people in the discovery of first- and second-order notions surrounding the R\&I.

Methodology

\subsection{Designing the prototype}

Our first challenge was to prototype an exhibit that combined on the one hand the predominant hands-on approach of contemporary science museums, with on the other hand a more rarely occurring contextual approach, also characterized as phase four museums [Hudson, 1987]. The hands-on approach requires a sequence of clear tasks for exploring science phenomena, immediately comprehensible to children [Hudson, 1987]. The contextual approach calls for a focus on the societal implications of research and innovation with attention to diverse viewpoints [Hudson, 1987]. Previous research has demonstrated that the use of the imagination can be useful to trigger divergent thinking [van der Meij, Broerse and Kupper, 2017]. As a result, we decided to design various imagination-triggering tools for the OL to facilitate frame reflection on the societal implications of potential SB applications.

Second, as many science museums use narratives [Allen, 2004; Stocklmayer, 2005], we chose to employ audio-narratives that present four ways of framing SB, based on a typology of SB framing extracted from focus group sessions among Dutch citizens [Betten, Broerse and Kupper, 2017]. Third, in line with the for science centres very common hands-on collaboration activities [Allen, 2004], we embedded a wooden puzzle, a drawing exercise and several conversation rounds in the prototype.

Furthermore, to create certain conceptual coherence [Allen, 2004] between the activities and conversations, we adopted framing theory of Grin and Graaf [1996] as outline for the sequence of user-exhibit and inter-user interaction: first reflection on first-order notions, then on second-order notions, ending with a final reflection on first-order notions again. As a result, the OL comprised a puzzle exercise as support in an introductory conversation; two rounds of listening and reflection on audio-narratives; and a drawing exercise as a round up.

As reflection on R\&I needs a 'focus' [van der Meij, Broerse and Kupper, 2017] e.g. on a practical R\&I application [Lynch, Klaassen and Broerse, 2017], we decided to make each OL session focus on SB organisms in either healthcare, sustainable development or food. Since potential applications of SB serve as a good subject for public dialogue and engagement [Engelhard, 2016], we chose applications in a conceptual stage of development. Aiming for reflection on reasonable extrapolation of R\&I [Nordmann, 2007], yet sparking the imagination of our participants for playful reflection [van der Meij, Broerse and Kupper, 2017], we inserted fictitious elements into the stories of the 'synthetic organisms'. We based the SB healthcare application on Budynek, Dabrowska, Skaradziński, and Górski's description of how bacteriophages can be synthesized to form a platform for cancer treatment [Budynek et al., 2010]. We called it the 'illness detecting and treating 
bacteriophage'. Although the currently created and tested phages are inserted by vaccination and merely slow down the growth of tumour cells [Budynek et al., 2010], we hypothesized that bacteriophages in the future might come in pill-form. The sustainable development application was rooted in an iGem project description of an E. coli MG1655, in which several Biobricks are introduced, by which it can potentially degrade PET plastic into non-toxic compounds. ${ }^{1}$ The iGem team had only proved this theoretically, yet Yoshida et al. 2016 work on comparable projects. We hypothesized that this bacterium would be able to eliminate plastic waste, like the 'plastic soup' in the ocean. The food application of SB was based on a study describing so-called C4 plants, created by means of CRISPR/Cas9 techniques that have an increased carbon fixation, resulting in efficient bio-mass production in hot and dry places [Lau et al., 2014, p 3]. Although crops are the only C4 plants that currently exist [Lau et al., 2014], we hypothesized that future fruit plants could use this technique too.

\section{The OL prototype}

In the OL, children (8-12 years) play 'synthetic biologist' for 20 minutes. Their mother or father is 'lab assistant', and the researchers, as prototype testers, facilitate each session. After an introductory exploration of the words 'biology' and 'synthetic', the child receives a physical, wooden puzzle of a fictitious cell nucleus with DNA 'blocks' (see Figure 1). Once the child has created a DNA sequence in this puzzle, a computer interface shows that it has created a 'synthetic organism' (see Figure 2). The facilitator presents one of the three contemporary SB applications as follows:

- A bacteriophage that 'destroys' diseases in your body. Scientists are trying to create organisms in such ways that they can be used as medicines for detection and destruction of diseases, like cancer, in your body.

- A bacterium that 'eats' plastic. Scientists are trying to change a bacterium like the ones normally found in your intestines, E. coli, so that it can digest plastic.

- A fruit plant that partly takes its nutrients 'from the air'. Scientists are trying to compose the DNA of a plant in such ways that it can grow almost anywhere in the world.

With the help of the computer interface (see Figure 2), the facilitator introduces the synthetic organism, after which the child is asked to share his/her opinion about it, and thereafter the parent. Then, they listen to four audio-narratives: Jack, Liv, Zoe and Dax; four fictional characters, each sharing their own opinion about the synthetic organism (see Figure 2 and appendix A). After listening to the narratives, the facilitator leads the children and parents in a process of reflection on their own views, the audio-narratives and the differences between them.

After the first sequence of initial opinion sharing, audio-narrative listening and reflection, follows a second round of deeper reflection by means of a 'deeper question' that depends on the organism created:

\footnotetext{
${ }^{1}$ http:/ /2012.igem.org/Team:UC_textunderscore Davis/Project.
} 


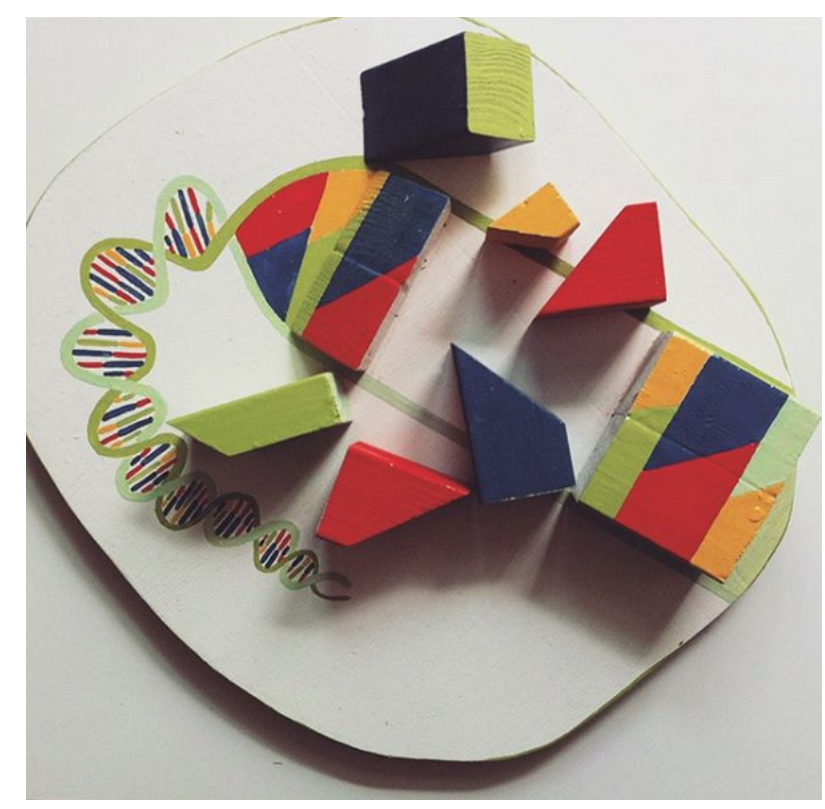

Figure 1. The DNA puzzle of the OL.

- Bacteriophage: When are you actually sick?

- Plastic eating bacterium: Are humans more important than nature?

- Fruit Plant: What is nature?

After an initial conversation about this deeper question, the child and parent listen to additional audio-narratives in which the same four characters provide their answer to this question. Having listened to the narratives, the child and parent are asked to reflect on the differences or similarities in their views again. Their initial opinions of the synthetic organism are discussed once more. In a 'round-up' step, the child is asked to draw its own invented future, with or without synthetic organisms.

\subsection{Testing the prototype}

We tested the OL in NEMO on five consecutive Wednesdays, between 11AM and $4 \mathrm{PM}$. The project was promoted on the NEMO website and flyers were provided at the entrance of the museum. A research assistant and the first author of this study recruited test session participants among the visitors present in the museum.

Children were asked for their age first, and if the child was between 8 and 12 years old, the researchers asked whether the child would like to join a 20-minute session on 'opinion forming about new science'. After agreement of the child and parent(s), the child would be invited inside 'the science learning lab' of NEMO with only one parent (See Figure 3). About $10 \%$ of the children and parents asked were willing to participate. Reasons given for rejection often were the own plans related to the museum visit, or concerns about 'getting home before the traffic jams'. In the end, 26 sessions could be conducted, with 13 girls and 13 boys enrolled in primary school, mostly aged between 9 and 11; only two kids were 8 and two were 12 years old. Furthermore, 10 mothers and 16 fathers participated, all aged 30 and up. 


\section{Welkom in het \\ Meningen-lab}

Welke kleur-code heb jij gemaakt?

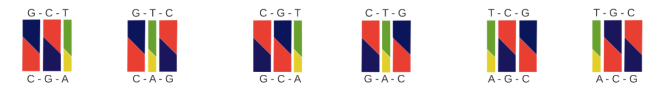

Cel van een bacteriofaag die ziektes vernietigt
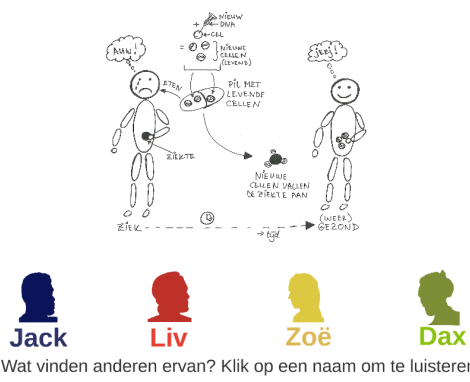

Cel van een bacterie die plastic opeet
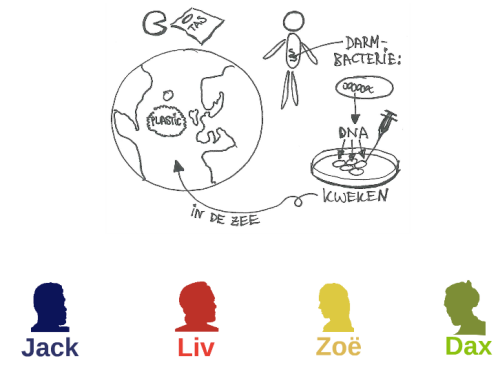

Wat vinden anderen ervan? Klik op een naam om te luisteren

Cel van een fruitplant die overal groeit

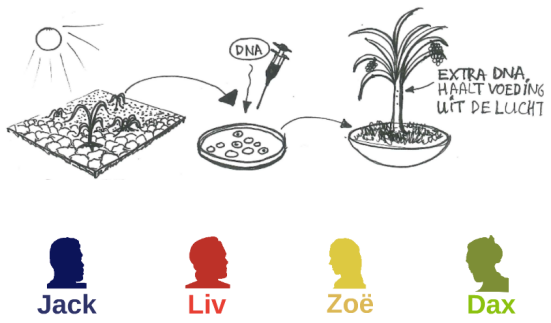

Wat vinden anderen ervan? Klik op een naam om te luisteren

Figure 2. Screenshots of the interface ${ }^{2}$ used in the OL test sessions (in Dutch). When clicking on a DNA combination in the home screen (on top), the interface navigates to visualizations of one SB application, and narratives of Jack, Liv, Zoë and Dax.

2See: https : //prezi.com/ajlpag0zem4a/?token=

76cba490b24a1be0b98b80a3448dcf 1291f2f c9b7244c3e1a9e568fb63498747. 


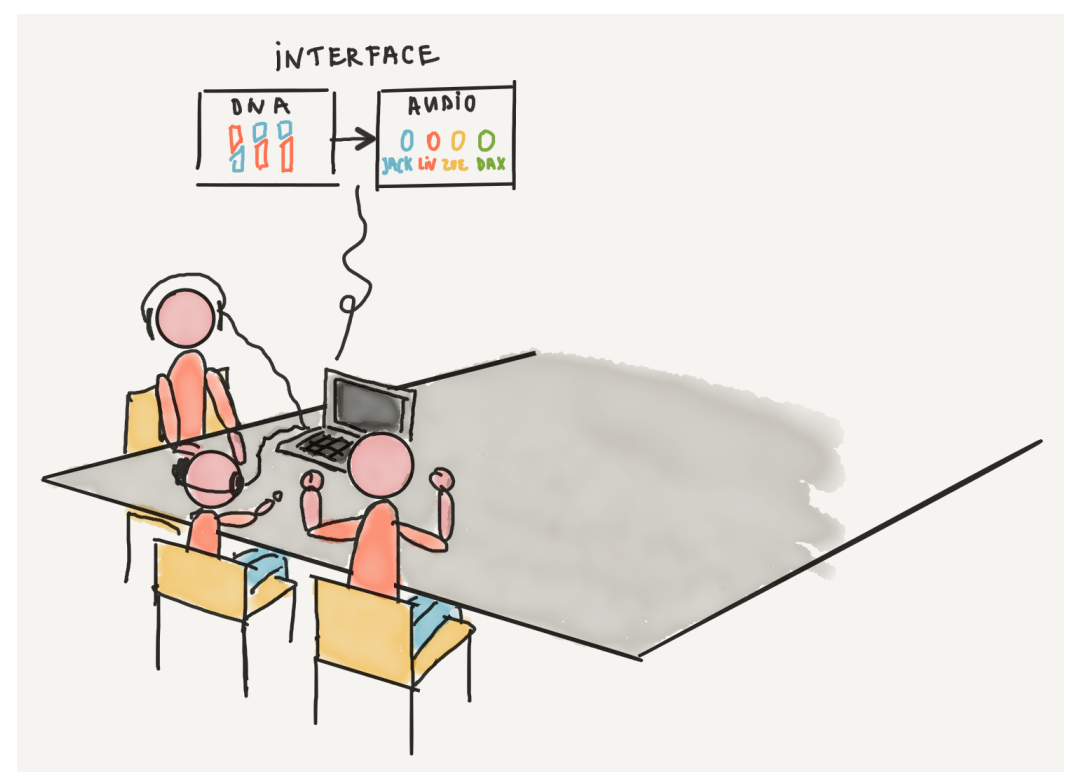

Figure 3. Artist impression of the OL test setting.

Although not asked explicitly, in the conversations it became clear that participants came from various parts of the Netherlands, varying between cities and more rural areas.

In the beginning of each session, we introduced the study purpose and procedures to the child and parent. After informed consent, an audio recording device was started. The first author acted as facilitator during test sessions, alternating with the research assistant, to guide the child and parent through each step as described in the prototype design above. After the drawing exercise, the child and parent were informed about the further research steps, after which they could continue their museum visit as intended. In the end, we did 10 sessions about the bacteriophage, 6 plastic eating E. coli sessions, and 10 fruit plant sessions.

\subsection{Data gathering, reduction and processing}

Based on the audio-recordings, each session was transcribed verbatim. The data was reduced to the level of participant-specific sentences [DeCuir-Gunby, Marshall and McCulloch, 2010], allowing us to analyse the frame reflection of children and parents separately. To make the frame analysis more explicit, data was separated (by session) in congruence with steps of the OL lab set-up: the first round of conversations, audio-narratives and reflection; the second round of conversations, audio-narratives and reflection; and the conversations during the drawing task.

\subsection{Data analysis and coding strategy}

We analysed sessions using the following approach. First, we analysed the initial conversations in which children and parents expressed their first opinions on the synthetic organisms. Based on inductive thematic coding of these initial views [Braun and Clarke, 2006], we identified several preliminary themes at the level of first-order notions. After discussion and agreement upon the preliminary codes 
between the authors, we used these same preliminary codes to analyse the conversations that took place after the first audio-narratives as well. New codes were identified and added to the preliminary code-set after verification of these new codes in multiple sessions about the same synthetic organism.

The same procedure was applied to the coding of the second round of talking, audio-narratives listening and reflection, albeit with new codes for the second-order notions. The final views of children and parents on the synthetic organism were compared to their initial views to identify the ways in which these views changed. Last, the notions shared during the drawing exercise were coded with the same codes as used in the first round of audio-narrative related analyses, making them comparable to initial and other views shared throughout the session. However, few patterns could be identified in these transcripts because children spoke very little during this exercise. After the coding, discussion about the coded data resulted in the identification and agreement upon several predominantly occurring reflection patterns.

Findings

Results are first presented in chronology of the OL: initial framing and developments in framing. Next we present the framing influencers that we have identified.

\subsection{Initial framings}

In general, first-order notions dominated the initial conversations with parents and children. This involved discussions about the possibilities and risks of synthetic organisms. Within these notions, several patterns could be identified. At the beginning of the sessions, children often welcomed synthetic organisms warmly as solutions for problems such as food scarcity in case of the fruit plant, treatment of illnesses in case of the bacteriophage, and prevention of environmental damage in case of the plastic eating $E$. coli. Their positive connotations ranged from considering the synthetic organisms as 'cool', 'funny' or 'useful'. Very occasionally, children expressed immediate concerns with regard to the synthetic organisms, mostly if they were in the older age group (10-12) or when the interviewer explicitly asked about possible risks.

Parents were initially slightly less enthusiastic about synthetic organisms. If they addressed positive aspects, they paid more attention to the potential of the synthetic organisms to tackle major issues at a global scale. It was mostly the parents who expressed concerns about the potential risks of synthetic organisms. These concerns focused on the unknown implications of the synthetic organism or general disagreement with the idea that human beings compose or change DNA of organisms.

\subsection{Developments in framing}

The initial framing of synthetic organisms by parents and children developed in various ways throughout the test sessions. First, we describe developments in ways of framing around the first round of audio-narratives. The patterns sometimes occurred in parallel or even mutually re-enforced each other. Illustrative quotes have been translated from Dutch to English. 


\subsubsection{Frame 'forming'}

At the beginning of many test sessions, children initially had difficulties in finding words to explain their opinion about the synthetic organism at stake in their session. Especially for these children, the audio-narratives helped them to identify their own views. The following fragment of session \#17, about the fruit plant, illustrates this well. The boy in this session initially considered the plant as 'handy', but was not able to explain his view with further comments. After hearing the first audio-narratives, he told the facilitator (F1):

Well, I agree with Zoë and not with Dax. (...) I do not agree with the idea [of Dax] that people change because that does not happen very soon, I think. (...) Zoë thought of having plants in your room, so that you have your garden in your room. That's handy! Then you do not have to buy your fruit anymore. So I like that. (C17)

This child expressed the further meaning of his initially mentioned 'handiness', while he also noted what he did not agree with.

\subsubsection{Incorporation of counter-arguments}

As the previous fragment showed to some extent, children also expanded their frames by adopting counter-arguments from the audio-narratives, involving enrichment or re-structuring of first-order notions. For example, in the beginning of session \#13, about the bacteriophage, the conversation went as follows:

F1: What do you think about this cell?

C13: Well, it's pretty special (...) and kind of funny that it works like this.

F1: Funny, and why you think it's special?

C13: Well I just think, 'a cell that fights against diseases'!

F1: Ok! And your mother?

P13: Yes I am also heavily impressed. Gosh, what an invention! (...)

After the audio-narratives, the conversation continued:

C13: I understand them all very well because Jack and Zoe considered it as good but Liv and Dax said something about the downsides (...)

F1: With whom do you agree?

C13: With Jack and maybe also with Zoë (...). Because if this cell really can do this, it would be very nice for science. Well, not for science. . . to fight against diseases. (...)

F1: (...) And why do you disagree with Liv and Dax?

C13: I do not really disagree but if this [bacteriophage] just really works, why would Liv and Dax still be negative about it? It's not necessary.

F1: (...) And what about your mother?

P13: I thought because 'you never know', Dax could also be right. (...). Some of this will come inevitably but you have to know the risks.

C13: I think so too. 
This extract shows that despite the initial enthusiasm of both participants, the parent identified an argument in the audio-narratives that gave a reason to become more cautious about the synthetic organism, which, in this case, the child agreed with.

\subsubsection{Extrapolation of the frame}

Incited by the audio-narratives, the participants occasionally started to imagine other potential uses or forms for the synthetic organism too, especially when they initially viewed the synthetic organism as a solution. If participants initially viewed the synthetic organism as problematic, participants compared the organism to alternative, non-synthetic solutions. The audio-characters 'Liv' and 'Zoë' seemed to trigger this pattern in particular. The following extract from session \#23, about the plastic eating E. coli, illustrates this. After disagreeing with Liv's argument that the cell could harm the ecosystem, the child told the facilitator (F2):

I cannot remember so well, but when she [Zoë] was talking, I considered her as the best (...) [namely] we can invent more cells. (...). Metal also ends up in the sea. So we can make a cell that cleans metal, and what more?! (C23)

Although Zoë speaks of 'ocean improvement', it was the child who invented the idea of cleaning metal in the sea. The parent, however, considered Jack as the 'best' character, for seeing this cell as a good solution to tackle the plastic soup in the ocean. Then the facilitator asked whether the parent and child would see this E. coli as 'the best solution', to which they answered:

C23: Well this [bacterium] really eats all plastic. And a boat could sometimes, for example, forget one plastic bag or 'miss it' while trying to catch it.

P23: So in that sense we could do both. The coarser work through a net [of a boat], and the smaller particles should still be filtered... Perhaps by this bacterium.

As these fragments of session \#23 show, the narratives did not only enrich the initial views of parents and children with counter-arguments but could also encourage further thinking.

\subsubsection{Frame deepening}

After the first round of reflection on audio-narratives, sessions about the fruit plant and the plastic eating E. coli addressed a deeper question about the meaning of nature and the relationship between nature and human beings. Test sessions about the bacteriophage addressed the meaning of illness. In analysing the conversations around these deeper questions, we identified one frame-deepening pattern. Before hearing the audio-narratives, children of the bacteriophage sessions described illness by its symptoms such as pain, fever, nausea and listlessness, while most parents considered illness as a condition in which one is not able to engage in daily or normal activities. Some parents made a distinction between curable and incurable illnesses, the difference between 'feeling ill' and 'being ill', and the influence of the individual on perceptions and incidence of illness. In the 
plastic-eating bacteria and plant sessions, most children defined nature as 'plants and animals'. Most parents added that these animals and plants are only natural if they are 'untouched by human beings'. Both parents and children often criticized the dominance of human beings in the relationship with nature, and the destructive impact of humans on nature.

After hearing the audio-narratives, children often agreed with one particular character. Based on this character they generally again stressed their own definitions of illness or nature as mentioned before the audio. The following quote from session \#24, about the plastic-eating bacteria, illustrates this:

C24: They all say something different. This time I agree with Zö̈ (...) because she was more or less the same [as me].

F2: Ok, do you know in what sense?

C24: Nope

F2: It's a feeling you have?

C24: Yes.

As the quote of this child demonstrates, elaboration on agreement with a character often remained absent, despite explicit questioning by the researcher. A quote from the parent in this same session illustrates a pattern that could be seen in responses of parents to the second audio-narratives, namely a general tendency to position themselves amidst multiple characters:

(...) It's a bit of a combination between Jack and Zoë (...) On the one hand ... I like Zoë saying we are part of nature. However, one cannot experience that so well in a cultivated, uhm, city... That we are part of it. But in the end that is true. However, the idea to improve the world, I am not so enthusiastic about that. (P24)

In the conversations about the deeper question, in which children often seemed to feel their initial answer confirmed by (one of) the narratives, views of parents and children also converged rather often. The following extract of session \#25 illustrates this. The child and parent were initially quite enthusiastic about the bacteriophage as a potential cure for diseases. When facilitator (F2) asked them When are you ill? the conversation took the following direction:

C25: Stomach pain and stuff (...) and headache too (...).

P25: Yes, if you cannot function normally. That can vary from lying in bed because you have flu or life-threatening conditions from which you can die, for example.

After hearing the audio-narratives, the conversion continued as follows:

C25: I agreed with Jack again. (...) Because he said when you have pain and stuff... when you have pain you are ill.

P25: For me, it was the second person, (...) Liv. (...) Who said that there has to be a label on everything these days (...) For me, too, some things are just part of life (...) And Jack hits the core of what I said earlier, about the notion that when you cannot function well, you are ill. 
The facilitator asked the child's opinion about Liv's notion as well, for which the conversation, after replaying of this audio-narrative, continued as follows:

C25: Yeah, I agree with Liv (...) because I think you should not say that you are ill too quickly.

F2: When would use the bacteriophage?

C25: I think you should only take it when you are really ill, and not just when you have some pain (...)

P25: Yes, I totally agree (...)

It seemed that the convergence made 'super-enthusiasts' (like C25) slightly more moderately enthusiastic about synthetic organisms, whereas initial 'critics' could grow appreciation for enthusiasm. The convergence resulting from deeper reflection seemed to nurture mutual understanding between children and parents when the opinions of the child and parent initially differed.

\subsubsection{Framagination}

In the analysis of conversations during the 'draw the future' exercise at the end of the session, we identified a repetition of the general notions that parents and children had shared up to that moment, albeit mostly in a more exaggerated form. For example, about a third of the children imagined that a utopia would emerge in which people would be completely happy and healthy, and synthetic organisms would solve all world problems. On the other hand, about a quarter of the children considered the potential risks of domination of technology over human beings. Occasionally, children predicted comical innovations for the future, such as a meatball tree, and flying humans. However, in about a third of the sessions, children emphasized as well that the world would stay more or less as it is now, although improved with some additional features. We should note that parents spoke very little during this exercise, as it was only the children who we asked to draw the future and explain their drawing.

\subsection{Factors influencing framing}

We identified three factors that influenced the framing: facilitation, child-parent interaction, and the design of the OL.

\subsubsection{Facilitation}

The facilitator guided the conversations, and hence to some extent influenced the frame forming, incorporation of counterarguments, frame extrapolation and converging processes of children and parents. For example, the facilitator monitored whether the children had remembered the audio well enough, occasionally leading to a replay of one or more audio-narratives. In the instances of replaying, the conversations clearly reached more depth and richness. Also, we saw that children would talk more when the facilitator asked them explicitly and systematically to share their own views before the parent would talk. When the 
facilitator did not provide this special opportunity, children would tend to answer more briefly, after which parents had a tendency to take over the conversation. When parents did this, children were less able to share their individual perspectives, which may have increased the degree of counter-argument incorporation and convergence of views. Furthermore, conversations were deeper and showed broader perspectives when the facilitator:

- Asked many 'why'-questions, especially in case of shy children (Tell me, why do you think it is 'cool'?),

- Acted as a buffer when parents were very dominant, particularly making sure that children had the opportunity to talk and also to disagree with their parents (You see this a bit different than your mum. Is that correct?).

- Made children and parents explicitly connect their answer to the deeper question with their initial view of the SB application, e.g. by asking whether they had changed their view of the SB application after listening to and reflecting on the second audio-narratives.

\subsubsection{Child-parent specific dynamics}

Inevitably, there were sometimes disagreements between children and parents. There were more disagreements in the sessions about the bacteriophage and the fruit plant while there were fewer disagreements about the plastic eating E. coli. In many sessions, we saw that children usually agreed with their parents especially if they had not expressed themselves in a lengthy way before the parent did. Still, in about a quarter of the sessions, children had a minor disagreement with their parents, either in their view of the synthetic organism or with regard to the second-order question. With support and encouragement from the facilitator and parents, children aged 10-12 years old were often enabled to make the child-parent differences explicit, but younger children found this especially difficult.

\subsubsection{Influences of the OL tools and exercises}

Processes that support reflection on R\&I inevitably trigger a particular framing of the R\&I [Macnaghten and Chilvers, 2014]. Indeed, the tools and exercises of the OL may have framed the children and parents to think in a particular way about SB. First, the puzzle in the test sessions might have presented SB as 'playing with nature' and 'giving scientists the opportunity to do what they want' [e.g. as described in Ancillotti et al., 2016]. In addition, our choice of synthetic organisms aimed at solving major problems in healthcare, sustainable development and food, may have encouraged a positive SB framing. Indeed, most children and parents were initially enthusiastic about SB's potential problem solving capacities. Although many children and parents changed their initial views during the sessions, the frame forming and furthering processes may have been shaped by the puzzle and application choice.

Second, the audio-characters' voices and terminology may have had a selective influence on framing processes. First, not all characters seemed to inspire the children or parents. For example, Dax seemed a rather complex character for many 
children, possibly due to his meta-level discourse, whereas kids often disliked Liv's criticism. Parents, however, often agreed with Liv's critical notions. Children often liked Zoë for her wild ideas, and possibly due to her enthusiastic voice, whereas parents sometimes considered her as absurdist. Nevertheless, it was also Liv who often stimulated the participants to counter-argument incorporation, while Zoë triggered more frame extrapolation. Jack, the pragmatist, seemed to have the greatest appeal to both parents and children especially in conversations about the deeper issues. We noted that Jack's straightforward way of addressing the deeper issues often evoked frame confirmation, especially after the second round of audio-narratives.

Furthermore, many children found it difficult to remember all four narratives, especially in the second round. This may have caused children to converge their view more quickly with that of their parents. We hypothesize that this memorization issue mostly occurred because listening to four characters in a row was quite a cognitive challenge for children, especially for the younger ones. It may have caused that in about a fifth of the sessions children still showed difficulties with elaborating on their views after hearing the second audio-narratives, especially when they were shy, younger than ten, or had difficulties concentrating for 20 minutes.

We also noted that the 'deeper questions' influenced the reflection on the SB application. The question 'are humans more important than nature?' evoked less in-depth reflection than the more open question 'what is nature?' or 'what is illness?' This had a impact on the degree to which frame confirmation and convergence occurred in the second round. Last, the drawing exercise did not trigger much discussion between parents and children, and thereby hardly yielded clear patterns in reflection. We could have stimulated more conversations for better elicitation of frames and thereby have furthered our analysis of frame reflection.

With this study, we identified that the Opinion Lab evoked three major first-order reflection patterns and one major second-order reflection pattern. First, the audio-narratives helped our case study participants, especially children, to find words to formulate their own framing. Second, we identified certain incorporation of counter-arguments, meaning the finding of new arguments that would nuance participants' initial thoughts concerning SB. Third, also certain frame extrapolation took place, characterized by thinking of new purposes for the synthetic organism or comparing it to alternative solutions to global issues. The frame-deepening pattern as the result of asking participants a 'deeper question' and reflection supported by a second round of audio-narratives comprised the identification with certain audio-characters, through which children and parents often re-emphasized their initial thoughts on the deeper question. Parents had a tendency to place their opinions between the views of two audio-characters, whereas children usually identified themselves with one particular character. However, children and parents did not often consider the reasons for the differences between their perspectives, if this was the case. Furthermore, we saw that the deepening question and audio-character identification could result in convergence between views of the child and parent. This suggests a nurturing of mutual understanding between child and parent, while maintaining the opportunity for differences of opinion. We saw that children, often slightly more enthusiastic about SB in the beginning, began to see 
risky aspects or at least understood that people could have other views than their own. Similarly, parents, often slightly more hesitant in the beginning of the sessions, were increasingly able to understand the child's or the audio-character's enthusiasm. The drawing exercise, however, did not appear to trigger very clear reflection patterns.

A limitation of this study is that of respondent bias. Since recruitment was based on self-selection, this yielded participants that had time to take part and were motivated to join the test sessions. This may have influenced the reflection patterns, for example the child's willingness to consider alternative viewpoints and incorporation of counter-arguments of the audio-characters or parent. Test sessions in other settings would be needed to reveal whether the patterns found in this study are representative.

\section{The potential value of playful reflection exhibits for RRI}

Based on the results of this study, we hypothesize that informal learning environments in science museums could support the reflection on R\&I for RRI purposes in various ways. OL's design elements, particularly the audio-narratives representing diverse ways of framing SB, supported participants to develop their own SB framing. This made it possible to elucidate differences of perspective between children and parents, occasionally triggering children and parents to accommodate or accept particular aspects of one another's SB framing. The reflection on second-order notions seemed to encourage respectful consideration of views other than their own. This effect is especially interesting for RRI-related reflection on R\&I, as that requires the elicitation of various views and the nurturing of mutual understanding [Macnaghten and Chilvers, 2014; Owen, Macnaghten and Stilgoe, 2012; Stilgoe, Owen and Macnaghten, 2013; Stilgoe, Lock and Wilsdon, 2014; Sykes and Macnaghten, 2013].

RRI depends on societal reflection processes that have an impact on R\&I policy [Owen, Macnaghten and Stilgoe, 2012; Stilgoe, Lock and Wilsdon, 2014; Sykes and Macnaghten, 2013]. A next step for science museums in facilitating reflection on R\&I then would comprise the systematic collection of citizen views of R\&I for policy purposes. As adult visitors of science museums would like to encounter exhibits that stimulate debate [Stocklmayer, 2005], exhibits for R\&I reflection might attract more adult visitors. Our study findings show that carefully designed tools can support visitors of science museums to express and reflect on their own and other opinions of R\&I. The OL was not a policy-motivated reflection effort, but further studies into comparable playful exhibit designs on emerging and controversial R\&I could investigate how science museums could systemically collect visitors' viewpoints with relevance to R\&I policy.

Towards exhibits for RRI reflection
Although some science museums will continue to inform visitors on science and technology, others might also be willing to play a role in RRI [Bandelli and Konijn, 2015]. In case the latter role is chosen, our study showed that science museums should take the following design elements into account in addition to the usual focus on hands-on, interactive exhibits [e.g. as discussed in Allen, 2004]. First, exhibits in science centres should focus on one or several particular future 
application(s) of an emerging and controversial R\&I field, instead of a field as a whole. When we asked children to do the DNA puzzle and explained the synthetic organism that they had fictitiously created with this puzzle, it seemed to provide participants with a good framework through which they could make sense of SB and its potential implications. This is consistent with findings of Lynch, Klaassen and Broerse [2017], who found that reflection on R\&I needs to be based on applications that are relevant to participants' own lives. In addition, case-specific reflection ensures that participants focus on a demarcated set of issues of the field, which creates the opportunity to elicit a broad diversity of visions [Lynch, Klaassen and Broerse, 2017].

Second, fictitious or futuristic elements on the specific R\&I application can stimulate discussion, but transparency is needed about the fictitious or futuristic elements too. We had incorporated fictitious elements into the information about each synthetic organism in the OL. These fictitious elements might have gone beyond reasonable extrapolations [Nordmann, 2007] and realistic expectations [Boerwinkel, Swierstra and Waarlo, 2014] of SB. However, Skydsgaard noted that curiosity-evoking triggers and potential scenarios in science museum exhibits are crucial to facilitate deep reflection [2016]. Indeed, the futuristic and fictitious synthetic organisms successfully triggered participants' imagination and reflection in our test sessions. Yet, we may have generated unfeasible expectations around the SB field. Also as sponsoring might be hard to realize when other sources of information than scientific content are presented [Macdonald and Silverstone, 1992], vast explicitness about the surrealism in the content, may prevent that sponsors get worried or visitors go home with a frightened or extremely exited idea of an application that does not even exist.

Third, embedding narratives in exhibits that represent opposing citizen viewpoints on R\&I are useful to trigger frame-diverse reflection on R\&I. Narratives are widely used in science museums to support science learning and reflection [Skydsgaard, Møller Andersen and King, 2016; Stocklmayer, 2005]. Our findings suggest that two audio-narratives may already be enough for children to reflect on R\&I, whereas more narratives can yield memorization issues. Namely, two of the four audio-characters in the OL, Liv and Zoë, seemed to support reflection best. Liv reflected dystopian thinking as demonstrated in the novel 'Brave New World' Aldous [Huxley, 1932] in which technology is developed in laboratories but eventually takes over all human hierarchies and interactions. Liv helped participants who were initially very enthusiastic to become more cautious, without damping their enthusiasm. Zoë, however, reflected a way of framing comparable to Spike Jonze's feature film 'HER' in which humans and technology physically and emotionally become 'one', with endless possibilities, although humans can still switch the technology 'off', after all [Bergen, 2014]. Zoë especially triggered our participants to imagine new ideas, also the initially cautious ones. The Liv and Zoë narratives were designed to be opposites in two dimensions: (1) Liv prefers a separation between technology and humans, while Zoë prefers them to merge; (2) Liv considers technology as dominant over humans, while Zoë considers humans as dominant over technology. Although this distinction, based on [Betten, Broerse and Kupper, 2017], may be valuable for reflection on SB only, we argue that especially multiple dimension-opposing narratives are effective to trigger reflection on R\&I. 
Finally, exhibits that stimulate reflection need a separate, safe environment and conversational guidance. In this study, the researchers acted as facilitators: inviting participants, providing information, giving instructions, making sure that children and parents had the opportunity to talk, and asking further questions to make them expand on their views. This appeared to be of great importance for the reflection processes. Given that children were easily distracted during the sessions, especially when listening to narratives, we argue that exhibits aimed at supporting reflection on R\&I may need a separate, quiet environment, where visitors can engage with their peers, family and facilitators. This is particularly important because science museums are generally highly dynamic, interactive and distracting environments [Allen, 2004]. Given that individual exhibits might facilitate inter-visitor reflection to a limited extent [e.g. in Delicado, 2009; Macdonald and Silverstone, 1992;

Stocklmayer, 2005], we argue that the explainers in science museums [Bandelli and Konijn, 2015] might need to take a new role: as reflection facilitators. For example, these staff could run 'reflection shows' a couple of times per day, inviting a limited set of visitors to read information and listen to narratives, and moderate conversations between them. As parents play a major role in supporting children in science learning in science museums [Allen, 2004], staff could also stimulate child-parent collaborations and conversations. We saw that the asking of questions about deeper notions, such as the meaning of technology, nature, science or life, already triggered deeper reflection than tools, such as narratives, did on their own. As a consequence, we argue that visitors can do first-order reflection independently, while staff could take the lead in asking second-order questions, and trigger visitors to create linkages between their answers. Further research into such exhibit environments in science museums could unravel weather and how the triggered reflection leads to mutual understanding of different viewpoints.

Acknowledgments Special thanks go to NEMO Science Museum and in particular Rooske Franse, who provided us the opportunity to use NEMO's Science Learning Lab, but also to Menno Hoogeveen, who supported in the data collection as research assistant, and to Sarah Cummings for her support in English editing. This study was made possible by the FP7 project SYNENERGENE, under Grant Agreement No:321488 of the Mobilization and Mutual Learning Action Plans (MMLAPs), funded by the European Commission. This funding subsidized dissemination about this project (conference talks), but had no involvement in the OL tool and case study design, data collection, analysis, interpretation or publication. 
Appendix A.

Audio-narrative transcripts
Bacteriophage (translated from Dutch)

\begin{tabular}{|c|c|c|}
\hline Character & $\begin{array}{l}\text { Audio-narrative script for the } \\
\text { first round: What do you think } \\
\text { about this bacteriophage? }\end{array}$ & $\begin{array}{l}\text { Audio-narrative script for the } \\
\text { second round: What is 'being } \\
\text { ill', actually? }\end{array}$ \\
\hline Jack & $\begin{array}{l}\text { Think of the diseases that these } \\
\text { phages could detect and treat. } \\
\text { Perhaps the time has come in } \\
\text { which we do no longer have to } \\
\text { accept that we die at a young } \\
\text { age. }\end{array}$ & $\begin{array}{l}\text { You're sick if you have some- } \\
\text { thing due to which you cannot } \\
\text { live or work normally. You have } \\
\text { pain, are sad, fatigued et cetera, } \\
\text { by a specific abnormality in your } \\
\text { body. Fortunately, we can often } \\
\text { solve things by means of medical } \\
\text { interventions. }\end{array}$ \\
\hline Liv & $\begin{array}{l}\text { Ok... a new type of cell in } \\
\text { your body? How do you en- } \\
\text { sure that the cell doesn't dam- } \\
\text { age you? And do I want } \\
\text { to know everything about my } \\
\text { body? Pretty scary, I think. }\end{array}$ & $\begin{array}{l}\text { Of course it is terrible to be really } \\
\text { sick. But the medical world can } \\
\text { also make you sick. Nowadays, } \\
\text { we say that we have a cold, al- } \\
\text { lergy, or ADHD rather quickly. } \\
\text { Remedies are being invented for } \\
\text { everything. But aren't diseases } \\
\text { just part of life? It seems that we } \\
\text { need to be more and more perfect } \\
\text { these days. }\end{array}$ \\
\hline Zoё & $\begin{array}{l}\text { How cool, with this [phage] } \\
\text { you do not only stay healthy, } \\
\text { you can become super-healthy! } \\
\text { Who knows what more we may } \\
\text { invent! I want to try such a } \\
\text { phage... }\end{array}$ & $\begin{array}{l}\text { Your health is something you are } \\
\text { in control of yourself. What } \\
\text { you eat and drink can make you } \\
\text { healthy or sick. You just have } \\
\text { to keep working on your body } \\
\text { to stay fit. If you can take } \\
\text { your health to a higher level } \\
\text { through technology, then surely } \\
\text { that's fantastic, right? Just don't } \\
\text { forget yourself, that's all. }\end{array}$ \\
\hline Dax & $\begin{array}{l}\text { This is actually a kind of liv- } \\
\text { ing computer in our body, due } \\
\text { to which we hardly have to } \\
\text { do anything by ourselves any- } \\
\text { more. A chance for a healthier } \\
\text { life. But what if we cannot live } \\
\text { without it anymore? }\end{array}$ & $\begin{array}{l}\text { Through scientific advances we } \\
\text { know more and more about } \\
\text { health and diseases. Old ideas } \\
\text { were rejected. But we must pay } \\
\text { close attention. Current ideas } \\
\text { perhaps will be obsolete again in } \\
\text { the future. So we need to keep } \\
\text { thinking about what 'being sick' } \\
\text { really means. }\end{array}$ \\
\hline
\end{tabular}




\begin{tabular}{|c|c|c|}
\hline Character & $\begin{array}{l}\text { Audio-narrative script for the } \\
\text { first round: What do you think } \\
\text { about this bacterium? }\end{array}$ & $\begin{array}{l}\text { Audio-narrative script for the } \\
\text { second round: Are humans more } \\
\text { important than nature? }\end{array}$ \\
\hline Jack & $\begin{array}{l}\text { I'm glad that with this tech- } \\
\text { nique the problem of the plastic } \\
\text { soup is solved. Human beings } \\
\text { must clean up the waste that is } \\
\text { created by human beings. }\end{array}$ & $\begin{array}{l}\text { Human beings can use nature. } \\
\text { But since we also desperately } \\
\text { need nature, we must do this } \\
\text { carefully. Plastic soup, or other } \\
\text { threats? Fortunately, mankind al- } \\
\text { ways invents new solutions for } \\
\text { these kinds of issues. }\end{array}$ \\
\hline Liv & $\begin{array}{l}\text { Can't we just use less plastic? If } \\
\text { we implement this [bacterium], } \\
\text { all sorts of scary organisms } \\
\text { might end up in the sea, while } \\
\text { they do not belong there. And } \\
\text { perhaps these organisms will } \\
\text { end up in our drinking water } \\
\text { eventually! }\end{array}$ & $\begin{array}{l}\text { We cannot live without nature. } \\
\text { Think of all the ways we depend } \\
\text { on nature: for our food, health, } \\
\text { environment, but also for our } \\
\text { leisure time. All these techniques, } \\
\text { such as cells that can possibly eat } \\
\text { plastic, they involve great risks. } \\
\text { If we destroy nature, we will cer- } \\
\text { tainly get it back at some point. } \\
\text { So we must be very careful. }\end{array}$ \\
\hline Zoë & $\begin{array}{l}\text { What an ingenious invention. } \\
\text { Maybe we can even make other } \\
\text { cells for the sea. Who knows } \\
\text { what we can improve on the } \\
\text { sea! }\end{array}$ & $\begin{array}{l}\text { Human beings are part of nature. } \\
\text { Mankind does not stand so much } \\
\text { above it, but has more power, for } \\
\text { which we can make certain de- } \\
\text { cisions about nature. However, } \\
\text { we must also have respect for the } \\
\text { wisdom of nature, since nature } \\
\text { can inspire us too. Nevertheless, } \\
\text { it would be very cool if we can } \\
\text { make something by which we can } \\
\text { improve nature. }\end{array}$ \\
\hline Dax & $\begin{array}{l}\text { We have to adapt ourselves to } \\
\text { new technologies that are in- } \\
\text { vented. If humans make those } \\
\text { cells, can't we just make them } \\
\text { so that the sea remains undam- } \\
\text { aged? }\end{array}$ & $\begin{array}{l}\text { Nature is infinitely large. Man- } \\
\text { kind is part of the same system, } \\
\text { but it takes only a modest place in } \\
\text { it. Nature is continuously chan- } \\
\text { ging so we must adapt along with } \\
\text { it. An important task lies there for } \\
\text { us as people to keep developing } \\
\text { ourselves. }\end{array}$ \\
\hline
\end{tabular}




\begin{tabular}{|c|c|c|}
\hline Character & $\begin{array}{l}\text { Audio-narrative script for the } \\
\text { first round: What do you think } \\
\text { about this plant? }\end{array}$ & $\begin{array}{l}\text { Audio-narrative script for the } \\
\text { second round: What exactly is } \\
\text { nature? }\end{array}$ \\
\hline Jack & $\begin{array}{l}\text { With this, we can solve a major } \\
\text { global problem: food shortage! } \\
\text { With this plant we may finally } \\
\text { have a solution for people with } \\
\text { hunger. We'd have to do it care- } \\
\text { fully, of course. }\end{array}$ & $\begin{array}{l}\text { If a plant grows and yields some- } \\
\text { thing, it's a plant. For centuries } \\
\text { we have selected the best plants } \\
\text { for our food, so if we adapt a } \\
\text { plant's cells it's not unnatural, } \\
\text { suddenly. Unnatural plants do } \\
\text { not exist. }\end{array}$ \\
\hline Liv & $\begin{array}{l}\text { Wait a minute. Fruit is some- } \\
\text { thing that you eat, right? Then } \\
\text { it enters your body... and what } \\
\text { happens next? And isn't it ter- } \\
\text { ribly expensive? Soon, there } \\
\text { might be only food for the rich! }\end{array}$ & $\begin{array}{l}\text { If human beings adjust anything } \\
\text { to a plant, it isn't a natural } \\
\text { plant anymore. We are pushing } \\
\text { this further and further it seems. } \\
\text { Where does it end? There is a } \\
\text { reason that the word 'unnatural' } \\
\text { exists. I would not eat it. }\end{array}$ \\
\hline Zoë & $\begin{array}{l}\text { Just imagine! We might be able } \\
\text { to grow an entire garden in our } \\
\text { houses, with lots of great new } \\
\text { plants. Strawberries that taste } \\
\text { like bananas and stuff. Cool } \\
\text { dude! }\end{array}$ & $\begin{array}{l}\text { Human beings are part of nature, } \\
\text { so we are just as natural as plants. } \\
\text { We try everything to improve } \\
\text { ourselves continually, but actu- } \\
\text { ally everything is naturally chan- } \\
\text { ging too, due to a variety of reas- } \\
\text { ons. So whatever we change to } \\
\text { plants, they are and will remain } \\
\text { part of nature. }\end{array}$ \\
\hline Dax & $\begin{array}{l}\text { If we do this, plants will become } \\
\text { very, very different. And agri- } \\
\text { culture too. How will these fruit } \\
\text { trees reproduce? And what will } \\
\text { the farmer do? Can we as hu- } \\
\text { mans, change too if we change } \\
\text { our food? }\end{array}$ & $\begin{array}{l}\text { What we see as 'nature' is based } \\
\text { on an agreement between people. } \\
\text { Over time, it changes too. Due to } \\
\text { technology, we live in a new sort } \\
\text { of nature, and soon enough there } \\
\text { will be something new again. } \\
\text { So we must continuously adapt } \\
\text { ourselves to that. }\end{array}$ \\
\hline
\end{tabular}

\section{References}

Allen, S. (2004). 'Designs for learning: Studying science museum exhibits that do more than entertain'. Science Education 88 (S1), S17-S33. DOI: 10.1002 /sce.20016.

Ancillotti, M., Rerimassie, V., Seitz, S. B. and Steurer, W. (2016). 'An Update of Public Perceptions of Synthetic Biology: Still Undecided?' NanoEthics 10 (3), pp. 309-325. DOI: 10.1007/s11569-016-0256-3.

Bandelli, A. and Konijn, E. A. (2015). 'Public Participation and Scientific Citizenship in the Science Museum in London: Visitors' Perceptions of the Museum as a Broker'. Visitor Studies 18 (2), pp. 131-149. DOI: 10.1080/10645578.2015.1079089.

Bandelli, A., Konijn, E. A. and Willems, J. W. (2009). 'The need for public participation in the governance of science centers'. Museum Management and Curatorship 24 (2), pp. 89-104. DOI: 10.1080/09647770902857497. 
Bergen, H. (2014). 'Moving "past matter": Challenges of intimacy and freedom in Spike Jonze's her'. Artciencia 7 (17), pp. 1-6.

Betten, A. W., Broerse, J. E. and Kupper, F. (2017). 'Dynamics of problem setting and framing in citizen discussions on synthetic biology'. Public Understanding of Science, pp. 1-16. DOI: 10.1177/0963662517712207.

Blümel, C. (2016). 'Enrolling the Toggle Switch: Visionary Claims and the Capability of Modeling Objects in the Disciplinary Formation of Synthetic Biology'. NanoEthics 10 (3), pp. 269-287. DOI: 10.1007/s11569-016-0276-z.

Boerwinkel, D. J., Swierstra, T. and Waarlo, A. J. (2014). 'Reframing and articulating socio-scientific classroom discourses on genetic testing from an STS perspective'. Science $\mathcal{E}$ Education 23 (2), pp. 485-507.

Boldt, J. (2016). Futures of technology, science and society. Wiesbaden, Germany: Springer Fachmedien Wiesbaden.

Braun, V. and Clarke, V. (2006). 'Using thematic analysis in psychology'. Qualitative Research in Psychology 3 (2), pp. 77-101. DOI: 10.1191/1478088706qp063oa.

Budynek, P., Dą̧rowska, K., Skaradziński, G. and Górski, A. (2010). 'Bacteriophages and cancer'. Archives of Microbiology 192 (5), pp. 315-320. DOI: $10.1007 / \mathrm{s} 00203-010-0559-7$.

DeCuir-Gunby, J. T., Marshall, P. L. and McCulloch, A. W. (2010). 'Developing and Using a Codebook for the Analysis of Interview Data: An Example from a Professional Development Research Project'. Field Methods 23 (2), pp. 136-155. DOI: $10.1177 / 1525822 \times 10388468$.

Delicado, A. (2009). 'Scientific controversies in museums: notes from a semi-peripheral country'. Public Understanding of Science 18 (6), pp. 759-767. DOI: $10.1177 / 0963662508098577$.

Dewey, J. (1910). How we think: A restatement of the relation of reflective thinking to the educative process. New York, D.C., U.S.A.: D.C. Heath \& Company.

Engelhard, M. (2016). Synthetic biology analysed. Tools for discussion and evaluation. Heidelberg, Berlin: Springer.

Gibbons, M. (1999). 'Science's New Social Contract with Society'. Nature 402, pp. C81-C84.

Grin, J. and Graaf, H. van der (1996). 'Implementation as communicative action'. Policy Sciences 29 (4), pp. 291-319. DOI: 10.1007/bf00138406.

Hudson, K. (1987). Museums of Influence. Cambridge, U.K.: Cambridge University Press. ISBN: 978-0521305341.

Hulst, M. van and Yanow, D. (2014). 'From Policy "Frames" to "Framing"'. The American Review of Public Administration 46 (1), pp. 92-112. DOI: $10.1177 / 0275074014533142$.

Huxley, A. (1932). Brave New World. New York, U.S.A.: Harper \& Brothers. ISBN: 978-0-06-085052-4.

Korthals, M. (2011). 'Deliberations on the Life Sciences: Pitfalls, Challenges and Solutions'. Journal of Public Deliberation 7 (1).

URL: http://www . publicdeliberation.net/jpd/vol7/iss1/art8.

Lau, W., Fischbach, M. A., Osbourn, A. and Sattely, E. S. (2014). 'Key Applications of Plant Metabolic Engineering'. PLoS Biology 12 (6). Ed. by S. Kamoun, e1001879. DOI: 10.1371/journal .pbio.1001879.

Lynch, D. H. J., Klaassen, P. and Broerse, J. E. W. (2017). 'Unraveling Dutch citizens' perceptions on the bio-based economy: The case of bioplastics, bio-jetfuels and small-scale bio-refineries'. Industrial Crops and Products 106, pp. 130-137. DOI: $10.1016 / j$. indcrop. 2016.10.035.

Macdonald, S. and Silverstone, R. (1992). 'Science on display: the representation of scientific controversy in museum exhibitions'. Public Understanding of Science 1 (1), pp. 69-87. DOI: 10.1088/0963-6625/1/1/010. 
Macnaghten, P. and Chilvers, J. (2014). 'The Future of Science Governance: Publics, Policies, Practices'. Environment and Planning C: Government and Policy 32 (3), pp. 530-548. DOI: $10.1068 / \mathrm{c} 1245$ j.

McKee, M. (2003). 'Excavating Our Frames of Mind: The Key to Dialogue and Collaboration'. Social Work 48 (3), pp. 401-408. DOI: 10.1093/sw/48.3.401.

Meij, M. G. van der, Broerse, J. E. W. and Kupper, F. (2017). 'Conceptualizing playfulness for reflection processes in responsible research and innovation contexts: a narrative literature review'. Journal of Responsible Innovation 4 (1), pp. 43-63. DOI: 10.1080/23299460.2017.1326258.

Nordmann, A. (2007). 'If and Then: A Critique of Speculative NanoEthics'. NanoEthics 1 (1), pp. 31-46. DOI: 10.1007/s11569-007-0007-6.

Owen, R., Macnaghten, P. and Stilgoe, J. (2012). 'Responsible research and innovation: From science in society to science for society, with society'. Science and Public Policy 39, pp. 751-760.

Piaggio, A. J., Segelbacher, G., Seddon, P. J., Alphey, L., Bennett, E. L., Carlson, R. H., Friedman, R. M., Kanavy, D., Phelan, R., Redford, K. H., Rosales, M., Slobodian, L. and Wheeler, K. (2017). 'Is It Time for Synthetic Biodiversity Conservation?' Trends in Ecology \& Evolution 32 (2), pp. 97-107. DOI: $10.1016 / \mathrm{j}$.tree.2016.10.016.

Rerimassie, V., Van Est, R., Stemerding, D., Van Keulen, R., Robaey, Z., Peters, M. and Malsch, I. (2016). 'Moderne biotechnologie in Nederland: Informatie ter voorbereiding AO Biotechnologie'. URL: https://www.rathenau.nl/nl/public atie/moderne-biotechnologie-nederland.

Schön, D. A. (1983). The reflective practitioner. How professionals think in action. New York, NY, U.S.A.: Basic Books.

Schön, D. A. and Rein, M. (1994). Frame reflection: Toward the resolution of intractable policy controversies. New York, NY, U.S.A.: Basic Books.

Skydsgaard, M. A., Møller Andersen, H. and King, H. (2016). 'Designing museum exhibits that facilitate visitor reflection and discussion'. Museum Management and Curatorship 31 (1), pp. 48-68. DOI: 10.1080/09647775.2015.1117237.

Stilgoe, J., Lock, S. J. and Wilsdon, J. (2014). 'Why should we promote public engagement with science?' Public Understanding of Science 23 (1), pp. 4-15. DOI: $10.1177 / 0963662513518154$.

Stilgoe, J., Owen, R. and Macnaghten, P. (2013). ‘Developing a framework for responsible innovation'. Research Policy 42 (9), pp. 1568-1580. DOI: $10.1016 / j$.respol .2013 .05 .008$.

Stocklmayer, S. (2005). 'Public awareness of science and informal learning - a perspective on the role of science museums'. URL: http://mps.uchicago.edu/d ocs/articles/Informal_Science_Susan_Stocklmayer_Think_Piece.pdf.

Sykes, K. and Macnaghten, P. (2013). ‘Responsible Innovation — Opening Up Dialogue and Debate'. In: Responsible Innovation, pp. 85-107. DOI: $10.1002 / 9781118551424$.ch5.

Yaneva, A., Rabesandratana, T. M. and Greiner, B. (2009). 'Staging scientific controversies: a gallery test on science museums' interactivity'. Public Understanding of Science 18 (1), pp. 79-90. DOI: 10.1177/0963662507077512. 
Marjoleine G. van der Meij is a researcher and teacher at the Science Communication department of the Athena Institute for Innovation and Communication in the Health and Life Sciences of VU University Amsterdam. She teaches various courses of the VU University's Science Communication Master programme. E-mail: m.g.vander.meij@vu.nl.

Jacqueline E. W. Broerse is full professor at the Science Communication department of the Athena Institute for Innovation and Communication in the Health and Life Sciences of VU University Amsterdam. E-mail: j.e.w.broerse@vu.nl.

Frank Kupper is an assistant professor at the Science Communication department of the Athena Institute for Innovation and Communication in the Health and Life Sciences of VU University Amsterdam. He is chief coordinator of all courses that are part of the VU University's Science Communication Master programme. E-mail: f.kupper@vu.nl.

\section{How to cite}

van der Meij, M. G., Broerse, J. E. W. and Kupper, F. (2017). ‘RRI \& science museums; prototyping an exhibit for reflection on emerging and potentially controversial research and innovation'. JCOM 16 (04), A02. 